uwalniającą od odpowiedzialności. Ograniczone są zatem i obszary badań, wolne od wątków egzystencjalnych, metafizycznych, etycznych. W zachodniej historiografii są one częściowo już od dawna obecne (Annales), bo wyszukiwanie nowych tematów w historii umożliwia identyfikowanie się z nią, jej rozumienie. Bo ilu wśród nas jest królem, księciem?

"Nowa" historia dotyka głównie średniowiecza, zajmuje się sprawami zwykłych obywateli, także dzieci i kobiet, opisuje zagadnienia życia codziennego, a problematyka gustów literackich, sekt religijnych, więzien, dróg, kanalizacji, drukarstwa, języka jest równie ważna jak wojny, pakty, sprawy dynastyczne. W tym zatem rozumieniu więc tytułowa „mikrohistoria" jest w swych intencjach jakościowa i miniaturowa, a nie ilościowa i globalizująca.

Bo przecież, jak zauważyła Ewa Domańska, humanista - historyk nie powinien pisać tylko dla siebie. Jego praca naukowa ma znaczenie w budowaniu świadomości i kształtowaniu wizji przyszłości; życia i przeszłości uczy nie historia bowiem, ale jej badacze i wartości, które sobą reprezentują. A to jest zadanie bardzo odpowiedzialne.

Wnioski Ewy Domańskiej są bardzo surowe i gorzkie dla historii i jej badaczy. Propozycje, dotyczące jej uprawiania (np. dotyczące [nie] doboru źródeł, ich interpretacji, sposób konstruowania narracji z wyraźnym zaznaczeniem obecności badacza, wprowadzanie do narracji dialogów) mogą być szokiem. Bo historyk ma być nie tylko interpretatorem i twórcą tego "co było" - ma stać się mediatorem pomiędzy przeszłością a teraźniejszością. Historia natomiast snem człowieka, uobecnionym rajem, codzienne zajęcia - rytualami, banat - mqdrościq. śmierć - poczqtkiem życia ${ }^{2}$.

Nie można jednak przejść po lekturze Mikrohistorii obojętnie. To obowiązkowa lektura dla odpowiedzialnych historyków. Bo jakiej przeszłości nam dziś potrzeba?

Edyta Glowacka-Sobiech

\title{
Instytut Historii Nauki Polskiej Akademii Nauk w latach 1953-2003. Ksiega jubileuszowa z okazji pięćdziesięciolecia dzialalności, pod red. Joanny Schiller i Leszka Zasztowta, Warszawa 2004, ss. 507.
}

W roku 2003 Instytut Historii Nauki Polskiej Akademii Nauk świętował jubileusz pięćdziesięciolecia działalności. Z tej okazji do rąk czytelnika trafiła obszerna praca, licząca 507 stron, autorstwa Joanny Schiller i Leszka Zasztowta pt. Instytut Historii Nauki Polskiej Akademii Nauk w latach 1953-2003. Księga jubileuszowa z okazji pięćdziesięciolecia dzialalności.

Ksiega jubileuszowa, którą przygotowano dla upamiętnienia minionego ćwierćwiecza ma charakter dokumentacyjny. Jak napisał w słowie wstępnym Henryk Samsonowicz,

\footnotetext{
s. 275.
} 
jest kroniką ludzkich poszukiwań prawdy, rejestracją osiągnięć i błędów, zapisem meandrów myśli badawczej. Stanowi też przypomnienie działań koryfeuszy nauki w Polsce, których trud zaowocował powstaniem Instytutu.

Księgę otwiera Kalendarium Instytutu, stanowiące zapis chronologiczny procesu tworzenia Pracowni Dziejów Oświaty i Zakładu Historii Nauki i Techniki oraz ich przekształceń, które doprowadziły Instytut do obecnego stanu. Powstanie Instytutu nastapiło wskutek połączenia dwóch placówek badawczych Polskiej Akademii Nauk utworzonych w latach 1953-1954, a mianowicie Pracowni Dziejów Oświaty i Zakładu Historii Nauki. Powstanie i rozwój pierwszej wiąże się z nazwiskiem profesora Lukasza Kurdybachy. Druga natomiast była dziełem profesora Bogdana Suchodolskiego. Półwiekowe dzieje rozwoju i działalności placówek, które złożyły się na Instytut Historii Nauki, to - jak podkreśla Kalina Bartnicka - historia pokonywania trudności organizacyjnych lat pionierskich, odpierania różnych nacisków ideologicznych i pracy badawczej mimo coraz bardziej drastycznych ograniczeń finansowych. Są też potwierdzeniem korzyści, jakie wynikały z ukierunkowanej perspektywicznie, systematycznej pracy zespołowej, jednoczącej we wspólnym wysiłku badawczym pracowników PAN i ludzi nauki z innych ośrodków akademickich.

Badania podejmowane i prowadzone w Instytucie Historii Nauki dotyczyly dziejów nauki, techniki i oświaty polskiej, i wypełniały „białe plamy” w istniejącym stanie wiedzy. Kierownicy placówek wytyczali dalekosiężne cele, którymi były obszerne syntezy historii oświaty i historii nauki polskiej. Te przedsięwzięcia wymagały wciagania do współpracy dużych zespołów samodzielnych badaczy, a także tworzyły niepowtarzalną szansę naukową szczególnie dla kształcenia młodej kadry badawczej. W efekcie powstawały liczne rozprawy, artykuły, monografie, które jednocześnie dawały podstawę do nadawania kolejnych stopni i tytułów naukowych zatrudnionym w placówkach pracownikom.

W ciagu półwiekowej działalności Instytut zgromadził duży potencjał materialny i intelektualny. Mieszczą się w nim nie tylko specjalistyczne zbiory naukowe, publikacje i czasopisma, ale także doświadczona kadra administracyjna. Placówka dysponuje doświadczeniami w zakresie dydaktyki akademickiej i kształcenia kadry naukowej. Ponadto cieszy się niesłabnącym prestiżem naukowym i starannie rozwijanymi kontaktami naukowymi ze środowiskami akademickimi w Polsce i zagranica. Jest to niewatpliwie cenny dorobek, którym może dysponować polska kultura i nauka, i który powinien być celowo i starannie rozwijany. Należy podkreślić, że Instytut skupia wokół placówki poważną grupę badaczy z całego kraju, dąży do konsolidowania środowiska akademickiego historii nauki, oświaty i techniki oraz do inicjowania wspólnych badań.

Materiał zaprezentowany w pracy został ujęty w trzech częściach. Część pierwsza zatytułowana Od Komitetu, Zakladu i Pracowni - do Instytutu zawiera dwa wspomnienia. Autor pierwszego, Józef Miąso, podjął trud zgromadzenia śladów obecności Pracowni Dziejów Oświaty. Autor prezentuje twórcę i wieloletniego kierownika Pracowni Lukasza Kurdybachę oraz zespół Pracowni, który przez wiele lat inspirował i koordynował badania nad dziejami edukacji i kultury umysłowej w skali ogólnokrajowej. Pracownia miała swój wkład w rozwój badań nad edukacją staropolską, nad polskim Oświeceniem i Komisją Edukacji Narodowej. Ogromną rolę w kształtowaniu autorytetu Pracowni odegrał 
Marian Falski. Duże zasługi położył na tym polu również Ludwik Chmaj, Karol Poznański, Feliks Araszkiewicz, Irena Szybiak, Stanisław Mauersberg, Józef Miąso oraz Kalina Bartnicka.

Drugie wspomnienie, autorstwa Witolda Sygoskiego, ukazuje genezę Komitetu Historii Nauki i Techniki PAN, i jego związki z ówczesnym Zakładem Historii Nauki. Autor przypomina fakt powstania Komitetu Historii Nauki i Techniki PAN. Powstał on na podstawie zapisu ustawy o PAN stwierdzającego, że przy Wydziałach Akademii mogą być powoływane komitety naukowe. Zadziwia jednak fakt, że mimo zachowania wielu dokumentów źródłowych, daty powołania Komitetu czy skład Komitetu są rozbieżne i raczej dezinformują o przeszłości tej instytucji. Jak podkreśla autor, przedstawiony obraz działalności Komitetu nie jest wyczerpujący, ale nie jest wykluczone, że gdzieś znajdują się dokumenty, których odnalezienie pozwoli w przyszłości dokładnie przedstawić współzależności występujące pomiędzy Komitetem a Zakładem i Instytutem Historii Nauki. Refleksje autora kończy lista przewodniczących Komitetu, od początku jego istnienia do chwili obecnej. Ma to stanowić pomost między przeszłością a teraźniejszością środowiska badaczy historii nauki.

Druga część pracy zatytułowana została Uczeni, koledzy, przyjaciele. Znajdujemy tutaj kilkanaście wspomnień reprezentujących twórców, kierowników i niektóre z wybitniejszych postaci Instytutu. Zbiór zawartych refleksji dotyczy wydarzeń i zespołów badawczych, działających w Instytucie lub wspomagających go, tak, jak pamiętaja to uczestnicy wydarzeń lub członkowie zespołów, najczęściej znających osobiście ludzi, których przedstawiają.

Stanisław Mauersberg poświęca swoje wspomnienia osobie Profesora Bogdana Suchodolskiego, wielkiego humanisty, zadziwiającego rozległością i różnorodnością zainteresowań naukowych. Jak podkreśla autor, B. Suchodolski cieszył się wielkim autorytetem i głębokim szacunkiem pracowników Instytutu i utytułowanych członków Rady Naukowej. W każdym szanował osobowość i przejawiał wyrozumiałość dla poglądów, których sam nie podzielał. Był świetnym organizatorem i kierownikiem licznych prac zbiorowych. O czym świadczy np. 13 tomowa Encyklopedia powszechna czy 9 tomowa Historia nauki polskiej. Stawiał wysokie wymagania innym, lecz najwięcej wymagał od siebie. Pracowników nauki własnym przykładem dopingował do ustawicznego podnoszenia kwalifikacji i rozwijania potencjalnych możliwości, a studentów potrafił zmuszać do myślenia i wypowiadania się, przy zachowaniu form swobodnej wymiany poglądów. Jego przemówienia były prawdziwą ucztą duchową, władał bowiem piękną, wytwomą polszczyzn̨, a audytorium czarował swoim głosem po aktorsku „ustawionym”. Chociaż zachowywał pewien dystans i powściągliwość w stosunkach z ludźmi, to równocześnie darzył ich dobrotliwą przychylnością. Na zakończenie swoich wspomnień S. Mauersberg dodaje, że Profesor B. Suchodolski był człowiekiem wolnym i twórczym, gdyż: Ludzie, którzy dojrzeli do życia twórczego, sq rzeczywiście i autentycznie ludźmi wolnymi (75).

Kolejna refleksja poświęcona jest także osobie Profesora Bogdana Suchodolskiego. Irena Stasiewicz-Jasiukowa swoje wspomnienia zatytułowała Przeszłość dla przyszłości Profesora Bogdana Suchodolskiego - historyka nauki portret intelektualny i zwyczajny. Autorka próbuje dotrzeć do nieprzeciętnej intelektualnej osobowości uczonego i wykreować intelektualny i zwyczajny portret Profesora poprzez napisane przez niego książki. 
Stanowią one bowiem nieocenione źródło materiałów, świadczących o jego intelektualnym formacie, a tym samym są tworzywem do intelektualnego portretu Profesora. Jak podkreśla autorka tylko w ten sposób można było ukazać „Przeszłość Przyszłości”. Profesor bowiem należał do osób, które nie lubiły mówić o sobie. Przyczyną tej niechęci było przeświadczenie, że jednostkowe dzieje nie mogą być wystarczającą przesłanką do szerszych uogólnień i intelektualnych inspiracji.

I. Stasiewicz-Jasiukowa przybliża czytelnikowi również i ten zwyczajny portret Profesora jako osoby, która nie przywiązywała zbyt wielkiej wagi do stanowisk. Jak podkreśla autorka, mogło to wynikać z faktu, że określone formaty intelektualne nie wymagaja wizytówek, dowartościowujacych je poprzez zajmowane stanowiska, posiadaja bowiem autorytet niezależny od czynników zewnętrznych (s. 99). Kończąc swoje refleksje I. Stasiewicz-Jasiukowa ukazuje nieznany z pewnością czytelnikowi świat myśli i przeżyć Profesora. Otóż, w okresie dokonujących się w Polsce przemian politycznych oraz narastających rywalizacji, nie próbowano dostrzegać jego naukowych fascynacji i intencji działań, nie próbowano dojrzeć jego zasług, dążących do pogłębiania narodowej świadomości kulturalnej. To przekreślenie wartości prac Wielkiego Uczonego było dla niego bolesnym zetknięciem z rzeczywistością. Poczucie klęski byto tak dotkliwe, że przyspieszylo ostateczne odejście [Profesora] ze świata, który raz jeszcze potwierdzil brutalnq rozbieżność między wielkościa Człowieka a miłościq ludzi (s. 106). Nic więc dziwnego, jak podkreśla autorka wspomnienia, że Profesor darzył autentycznym uczuciem dwa wierne mu psy, które były niezawodnymi przyjaciółmi w jego codziennym życiu.

Bardzo obszerny artykuł wspomnieniowy o Łukaszu Kurdybasze, twórcy Pracowni Dziejów Oświaty Polskiej Akademii Nauk, zaprezentowała Kalina Bartnicka. Jakkolwiek nazwisko Profesora kojarzy się większości historyków wychowania i rzeszom studentów, przede wszystkim, z potężnym podręcznikiem historii wychowania, to należy podkreślić, iż wybitnie przyczynił się on do rozwoju historii wychowania w Polsce, wzbogacając jej dorobek, organizując warsztat naukowy, kształcąc młodzież i ukierunkowując badania. Autorka przybliża czytelnikowi okres dorastania, studiów i kariery naukowej Profesora, następnie działalność emigracyjną w czasie II wojny światowej i na koniec okres powojenny po powrocie do Polski. $Z$ dużym wzruszeniem czytamy o rozpaczliwych staraniach Profesora w tym okresie o prawo do dydaktyki uniwersyteckiej i badań naukowych oraz o bardzo intensywnej pracy naukowej i organizacyjnej w Pracowni Dziejów Oświaty PAN. Kalina Bartnicka podkreśla też w swoich wspomnieniach, że Profesor Łukasz Kurdybacha był postacią nietuzinkową, ale trudną do jednoznacznej oceny. Był wymagający jako zwierzchnik i życzliwy jako promotor, ale wywoływał też respekt i obawy. O tym, jaki był stosunek Ł.Kurdybachy do uprawianej dyscypliny naukowej i odpowiedzialności za środowisko świadczy niewątpliwie moment ostatniej rozmowy Profesora, już u kresu swoich dni, z Józefem Miąso. W dowód zaufania przekazuje swojemu uczniowi i następcy „pałeczkę", rodzaj testamentu naukowego co do problematyki badawczej, kontynuacji rozpoczętych prac, pokierowania rozwojem naukowym młodszych kolegów. Uczciła go też ziemia, na której się urodził. Szkoła Podstawowa w Przemyślu przybrała imię Łukasza Kurdybachy.

Jerzy Dobrzycki przybliża czytelnikowi w swoich wspomnieniach Aleksandra Birkenmajera, pracownika Zakładu Historii Nauki i Techniki w latach 1955-1960. Jak pod- 
kreśla autor, formację intelektualną zawdzięczał on Uniwersytetowi Jagiellońskiemu i ściśle $z$ nim związanej tradycji rodzinnej. Zajmował się pracami nad edycją dzieł Mikołaja Kopernika oraz przygotowaniem syntezy historii astronomii w Polsce. Pod jego kierownictwem były też prowadzone prace nad dziejami astronomii, przede wszystkim średniowiecznej. Mimo upływu czasu prace A. Birkenmajera nie straciły na wartości. Ta aktualność, jak podkreśla J. Dobrzycki wynika zarówno z trwałych wartości poznawczych, jak i z perfekcji metody badawczej.

Piękny wiersz napisany przez Bolesława Orłowskiego, na cześć Profesora Jerzego Dobrzyckiego, poprzedza kolejne wspomnienie. Wiersz został ofiarowany Jubilatowi w dniu Jego siedemdziesiątych urodzin.

Jarosław Włodarczyk opisuje w swoim tekście sylwetkę Profesora Jerzego Dobrzyckiego (1927-2004), astronoma i historyka astronomii. Mało kto wie, jak podkreśla autor wspomnień, że Profesor stał się w latach 60 . XX w. autorem największej sensacji naukowej owej dekady w badaniach kopernikańskich. Był bowiem współodkrywcą planetoidy 1572 Posnania, pierwszej planetki dostrzeżonej przez polskich astronomów. Zasłynął również jako najwybitniejszy kartograf nieba gwiaździstego w Polsce drugiej połowy XX w. Pierwsze wydanie jego cieszącego się wielką popularnością wśród astronomów Atlasu nieba gwiaździstego widocznego w Polsce ukazało się w 1956 r. Edycja druga, przygotowana wspólnie z synem, Adamem Dobrzyckim, pojawiła się w 1989 r., a w nowym, rozszerzonym opracowaniu w $1997 \mathrm{r}$.

Wspomniany już wyżej Bolesław Orłowski jest autorem refleksji zatytułowanej: Profesor Waldemar Voisé (1920-1995). Autor w bardzo ciepłych słowach wspomina swojego kierownika. B. Orłowski podkreśla jego ogromne zalety charakteru i błyskotliwej inteligencji, a głównie szacunek dla innych i szczerą życzliwość dla ludzi. Te cechy osobowości Profesora integrowały zespół i powodowały, że miejsce pracy było przyjazne i atrakcyjne.

Wiele miejsca i refleksji poświęciła Profesorowi Waldemarowi Voisé również Irena Stasiewicz-Jasiukowa. Autorka odsłania wielowymiarowy portret Profesora. Z jednej strony ukazuje jego poszukiwania sensu istnienia, „wysp szczęśliwych” i form wspótżycia $\mathrm{z}$ czasem, z drugiej strony - osobę bezpośrednią w kontaktach $\mathrm{z}$ otoczeniem, dowcipną $\mathrm{i}$ błyskotliwą $\mathrm{w}$ rozmowie, wreszcie $\mathrm{z}$ innej strony widzimy jednostkę ograniczoną ramami norm postępowania, które obowiązują wszystkich bez wyjątku. Tekst wspomnieniowy zawiera zwięzłą relację autobiograficzną uzmysławiającą czytelnikowi rangę intelektualną Profesora i jego twórczą rolę w historii nauki i techniki zarówno w Polsce, jak i w skali międzynarodowej. Bibliografia jego publikacji liczy około 250 pozycji, w tym znaczna część jest obcojęzyczna.

Kolejne dwa wspomnienia dotyczą osoby Profesora Pawła Czartoryskiego, historyka nauki, badacza i wydawcy Kopernika, profesora w Instytucie Historii Nauki PAN. W pierwszym, Andrzej Biernacki, wspominając Profesora, wraca myślą do jego „rozłożystego” biogramu. Jako człowiek miał łatwość w nawiazzywaniu kontaktów z ludźmi, był dobrym kolega „, wysoce rozbudowanych stosunkach towarzyskich”, równocześnie amator sportowych wędrówek po górach, a przede wszystkim należycie i wielostronnie wykształcony pracownik nauki, udzielający się równolegle w kilku uniwersytetach, jak też $\mathrm{w}$ innych, rozmaitych placówkach, powiernik ważnych poczynan społecznych, przy tym 
w sprawach reprywatyzacji przedstawiciel królewskiej rodziny o polskim pokrewieństwie. Ta bogata spuścizna Profesora wprawiała w kłopot nawet osoby prowadzące katalog alfabetyczny w Bibliotece Uniwersytetu Warszawskiego, które sporządziły aż cztery odrębne hasła osobowe sub voce Czartoryski Paweł. A. Biernacki ukazuje również Profesora jako doskonałego naukowca na polu historii nauki. Przejawiał w sobie, jak wspomina autor, dwie dyspozycje, przede wszystkim umiejętność szczegółowych i wnikliwych studiów nad źródłami oraz umiejętność podejmowania i dokonywania szerokich syntez naukowych. W swojej pracy badawczej był erudytą i odznaczał się rzetelnością. W zakończeniu swoich wspomnień A. Biernacki, zwraca uwage czytelnika na jeszcze jeden ważny aspekt w życiorysie Profesora Pawła Czartoryskiego, a mianowicie na działalność w polskim oddziale Towarzystwa Szkół Zjednoczonego Świata, którego był twórca i organizatorem. Organizacja ta pozwoliła włączyć młodzież polską do ogólnoświatowego IB - systemu ,matury międzynarodowej”' i dalszych wyjazdów na studia zagraniczne oraz rozpoczęła podobne działania na wschodzie, w krajach dawnej Rzeczypospolitej.

Drugie wspomnienie o Profesorze Pawle Czartoryskim, Jan Malicki opiera na osobistej refleksji, opublikowanych pośmiertnie notach oraz na danych zawartych w teczce osobowej Profesora, przechowywanej w Instytucie Historii Nauki Polskiej Akademii Nauk. Jak sam zauważa, nie jest łatwo pisać o osobie, z którą blisko, przez wiele lat się współpracowało. Jednak, jak zapewnia, są one szczere i pełne głębokiej sympatii, która powstała mimo różnicy statusu i wieku. J. Malicki wspomina zarówno o kwestiach naukowych, jak i o bardzo zwyczajnych sprawach - anegdotach, powiedzeniach, zabawnych sytuacjach czy też o sławnych odpowiedziach Profesora. Autor podkreśla, że wielość zainteresowań i specjalności Profesora Pawła Czartoryskiego, powodowała, że każdy kolejny stopień formalnej kariery naukowej wykonywany był w ramach innej dziedziny nauki. Sprawiało to czasem trudność w krótkim i zwięzłym określaniu jego specjalności. Autor wspomnienia, odsłania wiele nieznanych czytelnikowi obszarów zainteresowań Profesora. Pisze o jego zaangażowaniu w wiele inicjatyw politycznych i publicznych, o Jego miłości do gór, taternictwa i turystyki, o działalności w międzynarodowym ruchu alpinistycznym. Poza tym o serdecznym i stałym zaangażowaniu w sprawy Śląska (już od czasu pisania dysertacji doktorskiej), następnie o zainteresowaniu problematyką wschodnią oraz sprawami „Solidarności”. Zwraca również uwage na działalność Profesora w Radzie „Przeglądu Wschodniego”, a później stałą pomoc i radę przy tworzeniu zrębów Studium Europy Wschodniej UW.

Stanisław T. Sroka i Ryszard Terlecki poświęcili swoje wspomnienie Profesorowi Stanisławowi Brzozowskiemu i krakowskiej filii Instytutu Historii Nauki. W roku 1956 Profesor Stanisław Brzozowski zostaje kierownikiem Zespołu Historii Nauk Rolniczych przy ówczesnym Zakładzie Historii Nauki i Techniki PAN. Jak wspominają autorzy refleksji, S. Brzozowski prowadził działalność Zespołu na trzech płaszczyznach: organizując zebrania naukowe Zespołu, zapewniając uczestnictwo członków Zespołu w sesjach naukowych i okolicznościowych konferencjach oraz inicjując i wspomagając członków Zespołu w działalności publikacyjnej. Jak podkreślają autorzy wspomnienia, osiągnięcia Profesora Stanisława Brzozowskiego i kierowanego przez niego Zespołu Historii Nauk Rolniczych stały się znaczącym dorobkiem polskiej historiografii rolniczej i uczyniły z Krakowa główny ośrodek badań dziejów polskiego rolnictwa i nauk pokrewnych 
w drugiej połowie XX w. Profesor S. Brzozowski był człowiekiem niezwykle pracowitym, niemal bez reszty poświęcającym swój czas pracy naukowej. Potwierdzają to liczne jego prace i publikacje. Publikował w Polskim stowniku biograficznym, Slowniku biologów polskich, Encyklopedii odkryć $i$ wynalazków, „Zeszytach Naukowych Wyższej Szkoły Rolniczej w Krakowie”, w „Kwartalniku Historii Nauki i Techniki”. Najwięcej prac opublikował w Studiach i Materiałach z Dziejów Nauki Polskiej. Profesor S. Brzozowski był bardzo wymagający wobec siebie, natomiast dla swoich uczniów i współpracowników nawet pobłażliwy. W pracy zawsze odznaczał się rzetelnością, wielką dokładnością, cierpliwością w poszukiwaniu źródeł, a równocześnie ogromną erudycją. Autorzy wspomnienia podkreślają także skromność i pobożność Profesora. Wynikała ona prawdopodobnie $\mathrm{z}$ tradycji rodzinnych, matka Profesora była bardzo pobożna, a podczas studiów prezesowała Sodalicji Mariańskiej Żeńskiej. Poza tym w rodzinie utrzymywana była pamięć o braciach babki, z których jeden był przeorem klasztoru dominikanów, a drugi księdzem diecezjalnym, a następnie jezuita. Pobożność nie pozwoliła mu pozostawić bez opieki swoich najbliższych i do końca swoich dni opiekował się chorymi siostrą i bratem.

Drugą część księgi jubileuszowej kończy wspomnienie Henryka Hollendra poświęcone Profesorowi Eugeniuszowi Olszewskiemu. Autor przybliża czytelnikowi wielkiego historyka nauki i techniki. Podkreśla, że właściwie niewiele informacji pozostało o jego życiu i upodobaniach, gdyż zazwyczaj zostały one przejęte od współpracowników, niż zasłyszane od samego Profesora. Ukazują zatem jego obraz cząstkowy. H. Hollender wspominając Profesora podkreśla nie tylko jego erudycję i perfekcjonizm, lecz także bezlitosny krytycyzm, który powodował, że żaden tekst - własny czy cudzy nie był nigdy gotowy, i zawsze znalazło się w nim coś do poprawienia. Był człowiekiem dystyngowanym, o nienagannych manierach, wykluczających wszelką poufałość, pozbawiony ekscentryzmu, a jak żartobliwie wspomina autor, jedyny, to upieranie się, aby jego imię pisać „Eugenjusz”, tak jak miał w akcie urodzenia. Profesor Eugeniusz Olszewski do końca swoich twórczych dni pozostawał wrażliwym i przenikliwym komentatorem tego wszystkiego, co się w historii nauki i techniki działo, do końca był zafascynowany światem poznania naukowego. Mimo iż cierpiał na chorobę Alzheimera, nigdy nie odebrała mu ona jego ujmującej osobowości.

Trzecia część Księgi Jubileuszowej zatytułowana została: Kierunki badań i ich twórcy. Zawiera ona wspomnienia i refleksje dotyczące wydarzeń i zespołów badawczych, działających w Instytucie lub wspomagających go, w taki sposób, jak zapamiętali je autorzy.

Józef Babicz przybliża informacje na temat: Historii nauk o Ziemi w Zakładzie Historii Nauki $i$ Techniki PAN. Szczególną uwagę zwraca na różnorodność tematyczną pierwszego okresu badań i cenione prace Profesora Bolesława Olszewicza w zakresie historii geografii i kartografii, a później kontynuatorki jego dzieł Wiesławy Wernerowej.

W ciekawy sposób prezentuje swoje jubileuszowe Refleksje wspomnieniowe Tadeusz Bieńkowski. Najpierw autor przywołuje pozostałe w pamięci wydarzenia z pracy $\mathrm{w}$ Instytucie Historii Nauki, Oświaty i Techniki. Jak podkreśla, była to praca pozwalająca poznać źródłowo literaturę staropolską i opanować technikę bibliografowania. Następnie opisuje epizod odnalezienia posaggu Staszica i jego losy w Instytucie Historii Nauki PAN. 
Wanda Grębecka swoje refleksje poświęciła pracy w Zakładzie Historii Nauk Przyrodniczych Zespołu Historii Botaniki. Dotyczą one przede wszystkim organizacji współpracy z ludźmi, reprezentujących różne zespoły badawcze.

Kolejni autorzy, Paweł Komorowski i Jarosław Kurkowski, prezentują wspomnienia dotyczące działalności Zakladu Historii Nauk Spotecznych Instytutu Historii Nauki PAN w latach 1969-2003. Autorzy opisują rozwój i zmiany organizacyjne Zakładu. Poza tym szczególne miejsce poświęcają wielodyscyplinarnej tematyce badawczej i publikacjom Zakładu. Wspomnienia dotyczą również organizowanych w Zakładzie zebrań naukowych, które odgrywały ważną rolę. Ich celem, jak podkreślają autorzy, była prezentacja wyników badań pracowników Zakładu i przedstawicieli szerokiego grona osób z nim współpracujących. Warto również zaznaczyć, że przez cały okres istnienia Zakładu, prowadzono aktywną współprace z zagranicznymi ośrodkami naukowymi. Charakter tej współpracy uległ zmianie $w$ drugiej połowie lat osiemdziesiątych, kiedy to coraz większą rolę zaczęły odgrywać kontakty „prywatne” $\mathrm{z}$ instytucjami i osobistościami świata nauki w zachodniej Europie.

Tadeusz Kowalik swoje wspomnienia zatytułował To były calkiem znośne lata. Autor opisuje działalność naukową w Zakładzie Historii Nauki i Techniki i represje „emitowane" spoza Zakładu. Bardzo ciepło wspomina swojego profesora, a jednocześnie przyjaciela Oskara Langego. Podkreśla, iż był to nie tylko największy erudyta, jakiego spotkał w życiu, ale zarazem człowiek o ogromnej dobrotliwości.

Danuta Kozłowska wspomina Zespól Historii Kartografii przez pryzmat organizowanych przez Zakład konferencji. Od momentu założenia Zakładu, to jest od 1975 r. konferencje organizowano początkowo raz w roku, później co dwa lata. Do $2001 \mathrm{r}$. Zakład zorganizował 21 konferencji. Oprócz organizowania konferencji Zakład Historii Kartografii zajmuje się także wydawaniem serii „Z Dziejów Kartografii”.

Autorka kolejnego wspomnienia, Barbara Kuźnicka, prezentuje z perspektywy 40 lat, działalność własną i współpracowników z historii farmacji. Ujęła to w kilku dziedzinach, a mianowicie: badawczej, edukacyjnej, organizacyjnej i edytorskiej. Szczególną uwagę zwraca na ukonstytuowanie się instytucji o różnych strukturach we wspominanym okresie (Zespół, Pracownia, Zakład, Sekcja Historii Chemii i Farmacji obecnie), współpracę z badaczami innych instytucji, a także stworzenie ogólnopolskiego ośrodka konsultacji. Całość wspomnień zamyka lista doktoratów i habilitacji z zakresu historii farmacji.

Wspomnienia i refleksje z lat 1965-1989 opisuje Leszek Kuźnicki. Autor prezentuje w nich osobiste odczucia, jakie towarzyszyły mu w działalności na polu historii i metodologii w Zakładzie Historii Nauki i Techniki PAN. W pamięci przywołuje Profesora Suchodolskiego, który był dla niego wzorem wybitnego intelektualisty, jednocześnie w kontaktach bezpośrednich, wyjątkowo miłym i skromnym człowiekiem. Opisuje również osoby Profesorów: Eugeniusza Olszewskiego i Józefa Miąso, z którymi łączyły go przyjazne i serdeczne stosunki.

Małgorzata Malewicz jest autorką kolejnego wspomnienia. Zatytułowała je Kongres Kopernikowski A.D. 1973. Autorka opisuje swój udział w przygotowaniu edycji i w pracach redakcyjnych serii Studia Copernicana oraz w przygotowaniach do Kongresu Kopernikowskiego. 
Refleksje nad pracą w Instytucie Historii Nauki PAN prezentuje Bolesław Orłowski. Swoje wspomnienia zatytułował następująco: O tym, czego się nie dowiecie z urzędowych sprawozdań (luźne wspomnienia z pótwiecza pracy w IHN PAN). Autor koncentruje się na zasługach Profesora Eugeniusza Olszewskiego w zakresie historii techniki w Polsce oraz zaistnienia Polski w tej dziedzinie na forum międzynarodowym. Dodaje poza tym, że stał się on jednym z ojców założycieli pierwszej międzynarodowej organizacji historyków techniki (ICOHTEC). Autor podkreśla, że uczestnictwo w spotkaniach tej organizacji, pod koniec lat 60 . było okazją do nawiązywania kontaktów z badaczami zagranicznymi, tym cenniejsza, że w tamtych czasach było jedyną sposobnością poznawania świata. B. Orłowski wspomina także wydarzenia z czasów Solidarności, które w istotny sposób wpłynęły na przewartościowanie kontaktów międzyludzkich w Zakładzie Historii Nauk Ścisłych, w którym wówczas pracował, ale było to także ważne wydarzenie dla dziejów Instytutu. Jego pracownicy mieli w tym chlubny udział, organizując wiele akcji o charakterze moralnym. Kończąc swoje wspomnienia, B. Orłowski ubolewa nad faktem, że starzejący się Instytut, zagrożony jest likwidacją. Ma jednak nadzieję, że nadejdą lepsze czasy, bowiem - jak pisze - likwidacja Instytutu byłaby katastrofą nie do odrobienia dla historii nauki i techniki w Polsce, a może nawet w Europie Środkowo-Wschodniej.

Jan Piskurewicz swoje wspomnienia poświęcił Zakładowi Historii Organizacji Nauki. Autor z trudnością przywołuje wyblakłe nieco wspomnienia z owych czasów, kiedy rozpoczął pracę w Zakładzie, gdyż okres ten kojarzy mu się przede wszystkim z wyborem Jana Pawła II na papieża i z kresem epoki gierkowskiej. W swoich wspomnieniach prezentuje on Profesora Bogdana Jaczewskiego, kierownika Zakładu, którego wspomina bardzo ciepło i serdecznie. J. Piskurewicz opisuje również innych pracowników Zakładu, między innymi: W. Rolbieckiego i jego zmagania $z$ zatwierdzeniem habilitacji oraz Z. Skubałę-Tokarska, prowadzącą prace redakcyjne nad przedsięwzięciem Instytutu, $\mathrm{Hi}$ storiq nauki polskiej. Wspomnienie kończy ocena znaczenia naukowego i naukowo-organizacyjnego Zakładu. J. Piskurewicz podkreśla, że w jego pamięci jawi się Zakład jako coś dalekiego, ale jednocześnie bliskiego poprzez ludzi, którzy byli z nim związani i odeszli, i którzy w dalszym ciągu są z nim związani, jak również przez wymierny dorobek naukowy, udokumentowany licznymi publikacjami.

Zofia Podgórska-Klawe i Bożena Urbanek są autorkami kolejnego wspomnienia poświęconego, Zespołowi, Pracowni i Zakładowi Historii Nauk Medycznych. Autorki prezentują dzieje powstania Zakładu i główne osiagnnięcia naukowe, które stanowiły cenny wkład w historię nauk medycznych. Szczególną uwagę czytelnika zwracają na opracowanie i wydanie słownika biograficznego lekarzy, który będzie stanowił ważną podstawę koniecznego w przyszłości opracowania syntezy rozwoju nauk medycznych XX w. Do osiągnięć Zakładu, autorki zaliczają popularyzowanie w środowisku lekarzy - historyków medycyny zagadnień metodologicznych i możliwości współpracy z przedstawicielami innych dziedzin nauki. Zwracają również uwagę na prace ukazujące się pod auspicjami Zakładu. Wzbogacają one polską historię medycyny o nowy kierunek, aplikujący różne modele uprawiania historiografii medycznej, w którym osią narracji publikowanych prac jest ewolucja świadomości.

Jerzy Róziewicz to autor kolejnego wspomnienia zatytułowanego: Moje pierwsze trzy lata w Zakladzie Historii Nauki i Techniki PAN (1965-1967). Refleksje swoje autor kon- 
centruje na przykrościach, jakich doznał w ówczesnym okresie, najpierw w związku $\mathrm{z}$ opublikowaniem artykułu na temat kontaktów naukowych polsko-radzieckich w dwudziestoleciu międzywojennym, a potem w związku z wydaniem książki po obronie dysertacji doktorskiej. W obydwu przypadkach cenzura utrudniała wydanie. W pierwszym „przyczepiła się" - jak wspomina autor - do fragmentów dotyczących udziału polskich uczonych w rewindykacji z ZSRR polskich dóbr kultury. W drugim przypadku cenzura nie przepuściła książki, egzemplarze zniszczono, a skład drukarski rozsypano. Książka w zmienionej wersji ukazała się dopiero po dziewięciu latach od uzyskania doktoratu, a autor wspomnienia uzyskał za nią ogólnopolską nagrodę sekretarza PAN.

Karolina Targosz zatytułowała swoje wspomnienia następująco: Czterdzieści dwa lata $w$ pięćdziesięciu. Jako jedna $z$ ostatnich osób, które rozpoczęły pracę w Zakładzie Historii Nauki i Techniki PAN, z pełnym entuzjazmem, w niezwykle interesujący sposób, opisuje swoją działalność naukową. Jak podkreśla, możliwość pracy naukowej zawdzięcza Profesorowi Henrykowi Baryczowi, który zauważył u niej zdolności do analiz źródłowych i samotnych badań. Jemu też zawdzięcza fakt szybkiego zdobywania kolejnych szczebli „kariery” naukowej, pilnowana i popędzana w osiaganiu stopni.

Ewelina Tylińska w swoich wspomnieniach opisuje dzieje Zespołu Historii Nauki Polskiej XIX w., który powstał w 1966 r. Wspomnienia kończy aneks, w którym w kolejności chronologicznej umieszczono autorów referatów prezentowanych na zebraniach Zespołu Historii Nauki Polskiej XIX w.

Refleksję nad problematyką wschodnią prezentuje Zbigniew J.Wójcik. Tytuł jego wspomnienia to: W strone problematyki wschodniej (O Komisji Syberyjskiej Komitetu Historii Nauki i Techniki PAN). Autor koncentruje się na działalności Komisji Syberyjskiej i jej poważnym udziale w badaniach nad obecnością Polaków w dziejach Syberii. Jak podkreśla autor, studia nad powiązaniami naukowymi polsko-syberyjskimi mogły się rozwinąć dzięki wielu sprzyjającym okolicznościom, a mianowicie: problemem zainteresowani byli specjaliści radzieccy, znaczenie w tym względzie miał Komitet Historii Nauki PAN oraz Instytut Historii Nauki PAN wraz z wydawnictwami. Istotne znaczenie miał również w tym względzie poważny dorobek naukowy B. Olszewicza, J. Babicza, J. Róziewicza, W. Wernerowej, D. Kozłowskiej i innych. W latach PRL problem ,syberyjski” - poza historykami ,zesłań" - podejmowali historycy nauk przyrodniczych, władze radzieckie natomiast tego nurtu historii raczej nie wspierały.

Swoimi wieloletnimi przemyśleniami dotyczącymi uprawiania historii subdziedziny chemii oraz spraw redakcyjnych podzielił się Stefan Zamecki. Autor w swoich wspomnieniach z satysfakcją podkreśla, że na swej drodze naukowej spotykał wielu wybitnych uczonych, których poglądy inspirowały go w dalszych poczynaniach badawczych. Wszystkie jego ksiażki opublikowane zostały w serii „Monografie z Dziejów Nauki i Techniki” wydawanej przez Instytut Historii nauki PAN. Niestety, jak ocenia w zakończeniu wspomnień autor, kondycja profesjonalnej historii dziedziny nauka, a w jej ramach historii subdziedziny chemia jest obecnie fatalna. Autor ma jednak nadzieję, że w przyszłości, systematyczne wprowadzanie historii dziedziny nauka do programów nauczania w uczelniach wydatnie wzmocniłoby kondycję tej metanauki w polskim życiu intelektualnym.

Trzecią część Księgi jubileuszowej kończy wspomnienie współautora dzieła Leszka Zasztowta. Autor prezentuje refleksje na temat badań wschodnich w Instytucie Historii 
Nauki PAN. Podkreśla, że coraz częściej w badaniach wschodnich odchodzi się od problematyki polskiej w kierunku prac omawiających istotne problemy narodów zamieszkujących terytoria na Wschodzie. Wskazuje, że widoczne jest odejście od polonocentryzmu w kierunku klasycznych badań z zakresu historii powszechnej i komparatystyki historycznej. Autor dokonując pobieżnego przeglądu „,wschodniego" dorobku naukowego IHN, podkreśla, że badania z zakresu historii nauki potwierdzają pod wieloma względami cywilizacyjną wspólnotę pomiędzy Polską a jej wschodnimi sąsiadami.

Osobną część Ksiegi stanowią materiały dokumentacyjne, takie jak: Bibliografia publikacji IHN PAN, wykazy pracowników, uzyskanych promocji akademickich oraz związanych z Instytutem komitetów i komisji. Pracę kończy indeks nazwisk.

Prezentowana praca jest pod wieloma względami wyjątkowa. Przede wszystkim przynosi ogrom informacji z działalności Instytutu Historii Nauki, dotychczas zupełnie nieznanych lub znanych jedynie fragmentarycznie i znajdujących się w rozproszonych źródłach. Oryginalność dzieła polega także na wiązaniu działalności Instytutu z dokonującymi się w tym czasie przemianami politycznymi i kulturalnymi. Praca zawiera też w sobie pewne elementy wzruszające i zabawne, co z pewnością można zaliczyć do zalet dzieła. Oryginalność książki polega również na tym, że teksty pisane były przez uczestników przedstawianych wydarzeń czy przez członków zespołów, z reguły znających osobiście ludzi, których przedstawiali.

Reasumując, Księge jubileuszowa można polecić jako godną uwagi lekturę nie tylko historykom wychowania, ale także badaczom innych dziedzin nauk historycznych.

Malgorzata Posluszna

\section{Joanna Król, Uchronić przed zapomnieniem - średnie szkoły ogólno- ksztalcąe $w$ województwie szczecińskim w latach 1945-1948, Wydaw- nictwo Naukowe Uniwersytetu Szczecińskiego, Szczecin 2005, ss. 187}

Jerzy Topolski pisząc o rodzajach narracji historycznej wspomniał o historii narodowej i regionalnej. Przedmiotem tej ostatniej jest jakiś region, czyli mającą swe wyróżniające cechy jakaś geograficzna przestrzeń, którą właśnie za region uznano! Autorka recenzowanej pracy, Joanna Król, zajęła się rozumianą i wyróżniającą się tak przestrzenią - województwem szczecińskim w kontekście badań nad dziejami szkolnictwa średniego ogólnokształcącego w latach 1945-1948. Napisana przez nią rozprawa jest monografią historyczno-pedagogiczna, w której zastosowano układ chronologiczno-problemowy.

Autorka pisząc o powodach zajęcia się tym regionem i tym zagadnieniem odwołała się do kwestii fundamentalnych dla człowieka (szczególnie współczesnego) - tożsamości i poczucia przynależności. Napisała bowiem, że w dobie wszechobecnej globalizacji tak

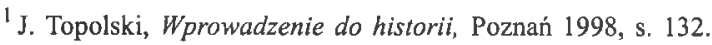

